\title{
Factors Associated with Low Intake of Dietary Fiber in Inflammatory Bowel Disease Patients
}

\author{
Vanessa Rosa Brito Oliveira1 ${ }^{1}$, Raquel Rocha ${ }^{{ }^{*}}$, Mirella Brasil Lopes ${ }^{1}$, \\ Fernanda Gomes Coqueiro ${ }^{1}$, Naiade Silveira Almeida ${ }^{1}$, \\ Sandra Santos Valois ${ }^{1}$, Genoile Oliveira Santana ${ }^{2}$ \\ ${ }^{1}$ Department of Sciences of Nutrition, School of Nutrition, Federal University of Bahia, \\ Salvador, Brazil \\ ${ }^{2}$ Gastroenterology Unit, University Hospital Professor Edgard Santos, Federal University of Bahia, \\ Salvador, Brazil \\ Email: raquelrocha2@yahoo.com.br
}

Received 5 April 2014; revised 10 May 2014; accepted 18 May 2014

Copyright (C) 2014 by authors and Scientific Research Publishing Inc.

This work is licensed under the Creative Commons Attribution International License (CC BY). http://creativecommons.org/licenses/by/4.0/

(c) (i) Open Access

\begin{abstract}
Inflammatory bowel disease patients reduce their intake of foods rich in dietary fibers in an attempt to prevent recurrence of the disease, predisposing these patients to nutritional losses. The aim of this study was to evaluate the intake of dietary fiber and associated factors in a group of patients with inflammatory bowel disease. This was a cross-sectional study with 61 inflammatory bowel disease patients, and all participants were outpatients in Salvador, Bahia. Patients completed a semi-structured questionnaire that included questions about demographics, socioeconomic status and anthropometric and clinical information and a food frequency questionnaire to assess the intake of dietary fiber. The mean intake of dietary fiber was $28.2 \pm 14.8 \mathrm{~g} / \mathrm{day}$ for inflammatory bowel disease patients, $27.9 \pm 10.1 \mathrm{~g} /$ day for ulcerative colitis (UC) patients and 28.9 $\pm 21.1 \mathrm{~g} /$ days for those with Crohn's disease (CD) (p > 0.05). Most inflammatory bowel disease patients $(52.5 \%)$ had intake below that recommended for dietary fiber. Inadequate consumption was present in $56.3 \%$ of CD patients and $43.8 \%$ of those with UC $(p=0.28)$. Men had lower fiber intake than women $(p=0.04)$. No significant associations between fiber intake and disease activity, location, presence of complications, gastrointestinal complaints, and nutrition counseling were found ( $p$ > 0.05). The low intake of dietary fiber was present in most patients, and the greatest inadequacy was found in males. Insufficient intake of dietary fiber appears to be linked to demographic features and not necessarily clinical characteristics relevant to inflammatory bowel disease.
\end{abstract}

"Corresponding author. 


\section{Keywords}

\section{Inflammatory Bowel Disease, Dietary Fiber, Eating}

\section{Introduction}

Inflammatory bowel disease (IBD) is a general term for a group of chronic inflammatory diseases involving the gastrointestinal tract and often refers to ulcerative colitis (UC) and Crohn's disease (CD) [1]. IBD has been a major problem in the gastroenterological westernized world [2].

IBD patients often worry about the foods that can trigger or exacerbate gastrointestinal symptoms (anorexia, nausea, vomiting, diarrhea, abdominal pain and distension), and they restrict their diet in an attempt to control symptoms or to prevent disease recurrence [3]. Fruits and vegetables are the most restricted foods by both CD and UC patients [4]-[8].

Some specific types of carbohydrates and fermentable fibers commonly found in some fruits and vegetables have been related to the onset or exacerbation of symptoms, such as pain, bloating and watery diarrhea, in patients with controlled IBD [9]. However, reducing the consumption of these foods involves reducing nutrient intake, dietary fiber, and antioxidants, predisposing individuals to nutritional loss [10]. In addition, diets low in dietary fiber may limit the synthesis of short chain fatty acids (SCFA), which are major fuels for colonocytes.

The aim of this study was to evaluate the intake of dietary fiber and associated factors in a group of IBD outpatients.

\section{Materials \& Methods}

\subsection{Patients and Study Design}

This was a cross-sectional study with patients receiving care at Nutrition and Gastroenterology Outpatient at a university hospital, which is a reference center for specialized care for IBD patient in the State of Bahia. The eligibility criteria for the study were a clinical, endoscopic, radiological and/or histological diagnosis of IBD [11], age more than 18 years, of both sexes. The exclusion criteria were pregnancy, previous gastrointestinal surgery, other inflammatory bowel diseases (colon diverticular disease of, hemorrhoids, irritable bowel syndrome) and limitations of neuromotor order.

The total of 65 IBD patients was recruited from September 2011 to March 2012. However, two patients were excluded because they presented with hemorrhoidal disease, and two were excluded for diverticular disease of the colon, resulting in a final sample of 61 patients.

\subsection{Evaluation Socio-Demographic and Clinical}

Demographic and socioeconomic data were collected by semi-structured questionnaire, which included questions about gender, age, level of education and income. Age was organized into quartiles, and income data were divided into tertiles of per capita family income and coded as $\leq 1$, between 1.1 and 3.5 and $>3.5$ times the minimum salary for the region. The number of years of education was grouped into $<1$ year, $1-8$ years, $9-11$ years and $>12$ years.

The disease activity index proposed by Harvey \& Bradshaw was used to determine the inflammatory activity in $\mathrm{CD}$, and if the value was below 5 index points, the disease was considered in remission. If the value was equal to or greater than 5, the disease was considered active [12]. The index created by Lichtiger was used for $\mathrm{CU}$, and clinical remission was defined as a score less than 10 points, while active disease was considered a score greater than or equal to 10 points [13].

The patients were questioned about the presence of gastrointestinal symptoms (diarrhea, nausea, vomiting, bloating and/or abdominal pain, bleeding in the stool). Information concerning the time of diagnosis, disease location or extent of intestinal involvement, presence of complications (fistula and fissure), and other associated diagnoses and medications were obtained from medical records. Data regarding disease location or extent of intestinal involvement were in accordance with the classification system of Montreal [14]. All patients reported regular use of prescribed medications. 


\subsection{Anthropometric Assessment}

Anthropometric measurements were taken in duplicate by trained and qualified professionals. Weight $(\mathrm{kg})$ and height $(\mathrm{cm})$ were measured with light clothing and without shoes using a scale with a coupled stadiometer from Filizola. The scale had a capacity of $150 \mathrm{~kg}$ and a resolution of $100 \mathrm{~g}$, and the stadiometer measured in $0.5 \mathrm{~cm}$ increments. The body mass index (BMI) was calculated from weight and height using the following formula: weight $(\mathrm{kg}) /$ height $^{2}\left(\mathrm{~m}^{2}\right)$. BMI cut points were used for classifying the anthropometric status. Different cut points were used for adults [15] and elderly adults [16].

\subsection{Evaluation of Dietary Fiber Intake}

To assess the daily intake of dietary fiber, patients answered a Quantitative Food Frequency Questionnaire (QFFQ). This QFFQ was validated for use in intervention studies and chronic disease prevention programs [17]. The QFFQ was administered in combination with a photo album of foods for more reliable data. The questionnaire contained 103 food items, food groups, beverages and supplements commonly consumed by the Brazilian population.

Daily dietary fiber intake (in grams) was calculated using the DietWin Personal program version 1.0 (DietWin, Porto Alegre, RS, Brazil). The established Adequate Intake (AI) values for fiber were used to examine the adequacy of fiber intake. For people between 19 and 50 years of age, the values were $38 \mathrm{~g} /$ day for men and 25 $\mathrm{g}$ /day for women. For people over 51 years old, the values were $30 \mathrm{~g} /$ day for men and $21 \mathrm{~g} /$ day for women [18].

Patients were also assessed for previous nutritional counseling and the use of dietary supplements. Any supplementation of dietary fiber reported by patients was not accounted for in calculations of fiber intake.

\subsection{Statistical Analysis}

For the descriptive analyses, we calculated the means with standard deviations (mean $\pm \mathrm{SD}$ ) for the continuous variables and the absolute and relative frequencies for the categorical variables. The chi-square test or Fisher's exact test was used to determine the strength of the association between two categorical variables. SPSS 17.0 software (SPSS, Chicago, IL, United States) was used for the statistical analyses. Statistical significance was set at $\mathrm{p}<0.05$.

\subsection{Ethical Considerations}

The study protocol was approved by the Ethics Committee in Research of the Complex Professor, Edgar Santos Hospital, Federal University of Bahia, under protocol number 50/11. All patients were informed about the study objectives and signed a Free and Informed Consent.

\section{Results}

Of the 61 IBD patients evaluated, 39 had UC and 22 had CD. The mean time to diagnosis was $7.0 \pm 4.3$ years for UC patients and $6.7 \pm 3.1$ years for CD. The disease was active in $7.7 \%$ of UC patients and $18.2 \%$ of those with $\mathrm{CD}(\mathrm{p}=0.24)$. Ulcerative proctitis $(51.3 \%)$ was the most frequent location of the disease in UC and colonic was the most frequent location in CD (40.9\%). The prevalence of normal weight patients, according to BMI, was independent of clinical diagnosis. Overweight patients accounted for $30.0 \%$ of IBD patients, while $22.7 \%$ of those with $\mathrm{CD}$ and $7.9 \%$ of those with UC were obese. Complications of the disease were more frequent in $\mathrm{CD}$ patients than in those with UC $(27.3 \%$ and $5.1 \%$, respectively, $\mathrm{p}=0.02)$, but gastrointestinal complaints were similar in both groups $(46.2 \%$ in UC and in CD 68.2\%, $\mathrm{p}=0.09)$ (Table 1).

\subsection{Demographic and Socioeconomic Characteristics}

In both diseases, $\mathrm{UC}$ and $\mathrm{CD}$, there was a predominance of females, $61.5 \%$ and $54.4 \%$, respectively. The mean age of CD patients was $39.9 \pm 9.7$ years and $46.1 \pm 13.8$ years in those with UC, $p=0.07$. Most of the UC patients $(51.3 \%)$ had a per capita income between 1.1 and 3.5 times the minimum salary, and those with CD (42.9\%) were more likely to have greater than 3.5 times the minimum salary, $p=0.36$. It was noted that most patients, $59.0 \%$ and $59.1 \%$ for UC and for CD, respectively, had 9 - 11 years of schooling (Table 1 ). 
Table 1. Description of the demographic, socio-demographic, anthropometric and clinical characteristics of the Crohn disease and ulcerative colitis patients.

\begin{tabular}{|c|c|c|c|c|}
\hline Variables & $\mathrm{UC}(\mathrm{n}=39)$ & $\mathrm{CD}(\mathrm{n}=22)$ & $\operatorname{IBD}(\mathrm{n}=61)$ & $\mathrm{p}$ \\
\hline \multicolumn{5}{|l|}{ Gender n (\%) } \\
\hline Male & $15(38.5)$ & $10(45.5)$ & $25(41.0)$ & \multirow{2}{*}{0.59} \\
\hline Female & $24(61.5)$ & $12(54.4)$ & $36(59.0)$ & \\
\hline Age (years) mean $\pm \mathrm{SD}$ & $46.1 \pm 13.8$ & $39.9 \pm 9.7$ & $43.8 \pm 12.8$ & 0.07 \\
\hline \multicolumn{5}{|l|}{ Schooling n (\%) } \\
\hline$<1$ years & $00(0.0)$ & $01(4.5)$ & $01(1.6)$ & \multirow{4}{*}{0.23} \\
\hline $1-8$ years & $11(28.2)$ & $03(13.6)$ & $14(23.0)$ & \\
\hline $9-11$ years & $23(59.0)$ & $13(59.1)$ & $36(59.0)$ & \\
\hline$\geq 12$ years & $05(12.8)$ & $05(22.7)$ & $10(16.4)$ & \\
\hline \multicolumn{5}{|l|}{ Income n (\%) } \\
\hline $1^{\circ}$ tercil $(\leq 1 \mathrm{MS})$ & $10(25.6)$ & $05(23.8)$ & $15(25.0)$ & \multirow{3}{*}{0.25} \\
\hline $2^{\circ}$ tercil $(1.1-3.5 \mathrm{MS})$ & $20(51.3)$ & $07(33.3)$ & $27(45.0)$ & \\
\hline $3^{\circ}$ tercil $(>3.5 \mathrm{MS})$ & $09(23.1)$ & 09 (42.9) & $18(30.0)$ & \\
\hline \multicolumn{5}{|l|}{ BMI classification n $(\%)$} \\
\hline Underweight & $04(10.5)$ & $03(13.6)$ & $07(11.7)$ & \multirow{4}{*}{0.37} \\
\hline Normal & $24(63.2)$ & $11(50,0)$ & $35(58.3)$ & \\
\hline Overweight & $07(18.4)$ & $03(13.6)$ & $10(16.7)$ & \\
\hline Obesity & $03(7.9)$ & $05(22.7)$ & $08(13.3)$ & \\
\hline Disease duration (years) mean $\pm \mathrm{SD}$ & $7.2 \pm 4.8$ & $6.7 \pm 3.1$ & $7.0 \pm 4.2$ & 0.62 \\
\hline \multicolumn{5}{|l|}{ Location of disease $\mathrm{n}(\%)$} \\
\hline Terminal ileum & - & $05(22.7)$ & - & \multirow{4}{*}{-} \\
\hline Colon & - & $09(40.9)$ & - & \\
\hline Ileocolon & - & $08(36.4)$ & - & \\
\hline Upper GI & & $00(0.0)$ & - & \\
\hline \multicolumn{5}{|l|}{ Extent of disease $n(\%)$} \\
\hline Distal & $20(51.3)$ & - & - & \multirow{3}{*}{-} \\
\hline Left-sided & $08(20.5)$ & - & - & \\
\hline Extensive & $11(28.2)$ & - & - & \\
\hline \multicolumn{5}{|l|}{ Disease activity n (\%) } \\
\hline Activity & $03(7.7)$ & $04(18.2)$ & $07(11.5)$ & \multirow{2}{*}{0.24} \\
\hline Remission & $36(92.3)$ & $18(81.8)$ & $54(88.5)$ & \\
\hline \multicolumn{5}{|l|}{ Complications of disease $\mathrm{n}(\%)$} \\
\hline Yes & $02(5.1)$ & $06(27.3)$ & $08(13.1)$ & \multirow{2}{*}{0.02} \\
\hline No & $37(94.9)$ & $16(72.7)$ & $53(86.9)$ & \\
\hline \multicolumn{5}{|l|}{ Gastrointestinal symptoms n (\%) } \\
\hline Yes & $18(46.2)$ & $15(68.2)$ & $33(54.1)$ & \multirow{2}{*}{0.09} \\
\hline No & $21(53.8)$ & $07(31.8)$ & $28(45.9)$ & \\
\hline
\end{tabular}

MS = Minimum Salaries; BMI = Body Mass Index; ${ }^{*} \mathrm{CD}(\mathrm{n}=21)$ e IBD $(\mathrm{n}=60), 01$ loss. 


\subsection{Intake of Dietary Fiber and Demographic and Socioeconomic Characteristics}

The inadequate intake of fiber was higher in men $(53.1 \%)$ than women $(46.9 \%)(p=0.04)$. No associations between low fiber intake and age, per capita income or study time were observed $(p=0.18, p=0.17$ and $p=0.36$, respectively) (Table 2).

\subsection{Intake of Dietary Fiber}

The mean intake of dietary fiber was $28.2 \pm 14.8 \mathrm{~g} /$ day for all IBD patients, $27.9 \pm 10.1 \mathrm{~g} /$ day for UC patients and $28.9 \pm 21.1 \mathrm{~g} /$ day for those with CD. Most of the IBD patients $(52.5 \%)$ had intake below the AI values. There was no association between restricting food sources of dietary fiber and counseling with a nutritionist, $\mathrm{p}=$ 0.68 (data not shown in table). Inadequate consumption of fiber was present in $56.3 \%$ of CD patients and $43.8 \%$ of those with UC $(p=0.28)$ (Table 3$)$.

Only one patient reported the use of supplemental dietary fiber.

\subsection{Intake of Dietary Fiber and Clinical Characteristics}

No associations between inadequate intake of dietary fiber and disease activity, location, presence of complications, or gastrointestinal complaints were observed $(\mathrm{p}>0.05)$ (Table 3$)$.

\section{Discussion}

In this study, the majority of patients consumed less fiber than the recommended amounts. These findings are consistent with studies that have shown an insufficient intake of dietary fiber in IBD patients [3] [6] [7] [19] [20]. Although a possible explanation for this result is the association that patients make between food sources of

Table 2. Adequacy of intake of dietary fiber according to demographic and socioeconomic aspects in inflammatory bowel disease patients $(n=61)$.

\begin{tabular}{|c|c|c|c|}
\hline \multicolumn{4}{|c|}{ Intake of dietary fiber } \\
\hline Demographic and socioeconomic aspects & Adequate $\mathrm{n}(\%)$ & Inadequate n (\%) & $\mathrm{p}$ \\
\hline \multicolumn{4}{|l|}{ Gender } \\
\hline Male & $08(27.6)$ & $17(53.1)$ & \multirow{2}{*}{0.04} \\
\hline Female & $21(72.4)$ & $15(46.9)$ & \\
\hline \multicolumn{4}{|l|}{ Age (years) } \\
\hline $20-35$ & $06(20.7)$ & $13(40.6)$ & \multirow{4}{*}{0.18} \\
\hline $36-44$ & $05(17.2)$ & $08(25.0)$ & \\
\hline $45-54$ & $10(34.5)$ & $06(18.8)$ & \\
\hline $55-74$ & $08(27.6)$ & $05(15.6)$ & \\
\hline \multicolumn{2}{|l|}{ Income } & * & \multirow{4}{*}{0.17} \\
\hline $1^{\circ}$ tercil $(\leq 1 \mathrm{MS})$ & $04(13.8)$ & $11(35.5)$ & \\
\hline $2^{\circ}$ tercil $(1.1-3.5 \mathrm{MS})$ & $15(51.7)$ & $12(38.7)$ & \\
\hline $3^{\circ}$ tercil $(>3.5 \mathrm{MS})$ & $10(34.5)$ & $08(25.8)$ & \\
\hline \multicolumn{4}{|l|}{ Schooling } \\
\hline$<1$ year & $0(0.0)$ & $01(3.1)$ & \multirow{4}{*}{0.36} \\
\hline $1-8$ years & $06(20.7)$ & $08(25.0)$ & \\
\hline 9 - 11 years & $20(69.0)$ & $16(50.0)$ & \\
\hline$\geq 12$ years & $03(10.3)$ & 07 (21.9) & \\
\hline
\end{tabular}

MS = Minimum Salaries; ${ }^{*} \mathrm{n}=60$ (01 loss). 
Table 3. Adequacy in fiber intake according to diagnosis and clinical features in inflammatory bowel disease patients $(\mathrm{n}=$ 61).

\begin{tabular}{|c|c|c|c|}
\hline \multicolumn{4}{|c|}{ Intake of dietary fiber } \\
\hline Clinical aspects & Adequate n (\%) & Inadequate $\mathrm{n}(\%)$ & $\mathrm{p}$ \\
\hline \multicolumn{4}{|l|}{ Clinical diagnosis } \\
\hline Ulcerative colitis & $21(72.4)$ & $18(56.3)$ & \multirow{2}{*}{0.28} \\
\hline Crohn's disease & $08(27.6)$ & $14(43.8)$ & \\
\hline \multicolumn{4}{|l|}{ Disease activity } \\
\hline Activity & $01(3.4)$ & $06(18.8)$ & \multirow{2}{*}{0.10} \\
\hline Remission & $28(96.6)$ & $26(81.3)$ & \\
\hline \multicolumn{4}{|c|}{ Extent/location of disease ulcerative colitis } \\
\hline Distal & $13(61.9)$ & $07(38.9)$ & \multirow{3}{*}{0.14} \\
\hline Left-sided & $05(23.8)$ & $03(16.7)$ & \\
\hline Extensive & $03(14.3)$ & $08(44.4)$ & \\
\hline \multicolumn{4}{|l|}{ Crohn's disease } \\
\hline Terminal ileum & $02(25.0)$ & $03(21.4)$ & \multirow{4}{*}{1.00} \\
\hline Colon & $03(37.5)$ & $06(42.9)$ & \\
\hline Ileocolon & $03(37.5)$ & $05(35.7)$ & \\
\hline Upper GI & $00(0.0)$ & $00(0.0)$ & \\
\hline \multicolumn{4}{|l|}{ Complications of disease } \\
\hline \multicolumn{4}{|l|}{ Fissure } \\
\hline Yes & $02(6.9)$ & $01(3.1)$ & \multirow[t]{2}{*}{0.60} \\
\hline No & $27(93.1)$ & $31(96.9)$ & \\
\hline \multicolumn{4}{|l|}{ Fistula $^{*}$} \\
\hline Yes & $01(12.5)$ & $04(28.6)$ & \multirow[t]{2}{*}{0.61} \\
\hline No & $07(87.5)$ & $10(71.4)$ & \\
\hline \multicolumn{4}{|l|}{ Gastrointestinal symptoms } \\
\hline \multicolumn{4}{|l|}{ Bleeding } \\
\hline Yes & $05(17.2)$ & $03(9.4)$ & \multirow[t]{2}{*}{0.46} \\
\hline No & $24(82.8)$ & $29(90.6)$ & \\
\hline \multicolumn{4}{|l|}{ Abdominal pain } \\
\hline Yes & $04(13.8)$ & $09(28.1)$ & \multirow[t]{2}{*}{0.22} \\
\hline No & $25(86.2)$ & $23(71.9)$ & \\
\hline \multicolumn{4}{|l|}{ Nausea } \\
\hline Yes & $02(6.9)$ & $06(18.8)$ & \multirow{2}{*}{0.26} \\
\hline No & $27(93.1)$ & $26(81.3)$ & \\
\hline \multicolumn{4}{|l|}{ Vomiting } \\
\hline Yes & $01(3.4)$ & $02(6.3)$ & \multirow{2}{*}{1.00} \\
\hline No & $28(96.6)$ & $30(93.8)$ & \\
\hline \multicolumn{4}{|l|}{ Diarrhea } \\
\hline Yes & $03(10.3)$ & 07 (21.9) & \multirow{2}{*}{0.31} \\
\hline No & $26(89.7)$ & $25(78.1)$ & \\
\hline \multicolumn{4}{|l|}{ Bloating } \\
\hline Yes & $10(34.5)$ & $10(31.3)$ & \\
\hline No & $19(65.5)$ & $22(68.8)$ & 0.78 \\
\hline
\end{tabular}

*Applicable only for Crohn's disease patients. 
fiber with the onset or exacerbation of symptoms, we found no association with clinical characteristics. We only found one association with gender.

Low fiber intake is a common condition in developing countries, and the Brazilian population is no exception [21]. The World Health Organization (WHO) and the Food and Agriculture Organization (FAO) published results on this issue, revealing that only $5 \%-25 \%$ of the population follow the current guidelines on dietary fiber intake [22]. Although there is some evidence, epidemiological studies are on the presence of an association between lower intake of dietary fiber and low family income, low education level and younger age [23]-[26]. In this study, we also did not observe these associations. Men had lower fiber intake, which agrees with the study by Figueiredo et al. (2008) [23]. It appears that male subjects are less concerned about health and body image and therefore consume fewer fruits and vegetables than women consume.

Dietary fibers are among the dietary components that exert a protective effect on predisposition for IBD and colon cancer [27]. One of the mechanisms that supports the association between fiber intake and the risk of these diseases is the production of butyrate as a result of bacterial fermentation of fibers in the colon. This and other short chain fatty acids have received considerable attention due to their possible influence on the inflammatory response. Experimental studies suggest that butyrate, for example, is able to downregulate the production of pro-inflammatory cytokines and activate nuclear factor kappa B (NF-kB) [28] [29]. Furthermore, fiber plays a key role in maintaining intestinal barrier function and gut microbiome balance [30]. Hallert et al. (1991) concluded that supplementation with Plantago ovata (PO) resulted in fewer gastrointestinal symptoms in IBD patients [31]. In another study, supplementation with PO proved effective in preventing relapses during drug therapy [32].

However, some studies found a relationship between a group of carbohydrates and fermentable fibers called FODMAPs (Fermentable Oligo-saccharides, Di-saccharides, Mono-saccharides And Polyols), which are found in some vegetables and fiber supplements, and the onset of the symptoms in IBD patients in remission. The hypothesis is that these fibers would be rapidly fermented, favoring bacterial overgrowth and excess gas production, resulting in bloating, abdominal pain and watery stools [9]. According to Richman \& Rhodes (2013), a diet low in FODMAPs would be useful in IBD patients who have persistent symptoms despite using conventional treatments for IBD activity [33]. However, the role of dietary components in the pathogenesis of IBD remains unclear, and there is little evidence for the effectiveness of restricting FODMAPs or consuming a low-fiber diet in IBD patients [34].

Although no association was found between the restriction of dietary fiber sources and counseling with a nutritionist, the recommendations of health professionals may also justify the dietary restrictions of fibers in IBD patients. These recommendations may be justified because many diets prescribe low residue foods to minimize or prevent gastrointestinal symptoms and bacterial overgrowth in the active phase of the disease [8]. However, many patients maintain this restriction during periods of remission [3] [7] [19], which may contribute to the results reported here.

$\mathrm{CD}$ and $\mathrm{CU}$ are distinguished by the location and severity of the disease. It is known that CD patients may develop more severely. However, in this study, there were no significant differences in the relationship between fiber intake and the clinical characteristics of either disease. Furthermore, both forms of the disease profoundly affect the quality of life of patients and have been increasing in incidence and prevalence in recent years [35] [36].

Society's eating habits, the advice of health professionals to consume restrictive diets and the strong association that IBD patients make between the intake of fruits and vegetables and symptomatology are all important risk factors that can lead to inadequate food intake and, thus, nutritional deficiencies. The exclusion of these foods in the usual diet, besides reducing fiber intake, contributes to the low intake of micronutrients and antioxidants, such as folic acid [10]. Recent studies do not yet know to what extent these nutritional deficiencies may negatively influence disease progression. Therefore, investigations into the intake of each nutrient are important for clinical practice to better guide the evaluation and treatment of these patients.

This study has some limitations, such as sample size, absence of a control group, the fact that patients who agreed to participate in this type of study may have different eating habits, the lack of differentiation of the various sources of dietary fiber consumed, and the use of a food frequency questionnaire that is subject to memory bias and changing eating habits related to disease symptoms. These disadvantages make it necessary to conduct further longitudinal studies to examine the relationship between the intake of fiber from different sources and IBD. 


\section{Conclusion}

IBD patients are a population at risk for protein-energy and micronutrient malnutrition. Insufficient consumption of dietary fiber in IBD patients was shown to be associated with population aspects and not necessarily relevant to clinical disease characteristics. It is necessary to increase patients' motivation to have healthy eating habits that include the adequate intake of fiber-rich foods and to assess each patient individually to avoid unnecessary dietary restrictions and greater injury to the health of these individuals.

\section{Declared Conflict of Interest of All Authors}

None.

\section{References}

[1] Podolsky, D.K. (2002) Inflammatory Bowel Disease. The New England Journal of Medicine, 347, 417-429. http://dx.doi.org/10.1056/NEJMra020831

[2] Ekbom, A. (2004) The Epidemiology of IBD. Inflammatory Bowel Disease, 10, 32-34. http://dx.doi.org/10.1097/00054725-200402001-00007

[3] Ripoli, J., Miszputen, S.J., Ambrogini Jr., O. and Carvalho, L. (2010) Nutritional Follow-Up of Patients with Ulcerative Colitis during Periods of Intestinal Inflammatory Activity and Remission. Arquivos de Gastroenterologia, 47, 49-55. http://dx.doi.org/10.1590/S0004-28032010000100009

[4] Mayberry, J.F., Rhodes, J. and Newcombe, R.G. (1978) Breakfast and Dietary Aspects of Crohn's Disease. British Medical Journal, 2, 1401. http://dx.doi.org/10.1136/bmj.2.6149.1401

[5] Kasper, H. and Sommer, H. (1979) Dietary Fiber and Nutrient Intake in Crohn's Disease. The American Journal of Clinical Nutrition, 32, 1898-1901.

[6] Thornton, J.R., Emmett, P.M. and Heaton, K.W. (1979) Diet and Crohn's Disease: Characteristics of the Pre-Illness Diet. British Medical Journal, 2, 762-764. http://dx.doi.org/10.1136/bmj.2.6193.762

[7] Jowett, S.L., Seal, C.J., Phillips, E., Gregory, W., Barton, J.R. and Welfare, M.R. (2004) Dietary Beliefs of People with Ulcerative Colitis and Their Effect on Relapse and Nutrient Intake. Clinical Nutrition, 23, 161-170. http://dx.doi.org/10.1016/S0261-5614(03)00132-8

[8] Zallot, C., Quilliot, D., Chevaux, J.B., Peyrin-Biroulet, C., Guéant-Rodriguez, R.M., Freling, E., Collet-Fenetrier, B., Williet, N., Ziegler, O., Bigard, M.A., Guéant, J.L. and Peyrin-Biroulet, L. (2013) Dietary Beliefs and Behavior among Inflammatory Bowel Disease Patients. Inflammatory Bowel Disease, 19, 66-72. http://dx.doi.org/10.1002/ibd.22965

[9] Gibson, P.R. and Shepherd, S.J. (2005) Personal View: Food for Thought-Western Lifestyle and Susceptibility to Crohn's Disease. The FODMAP Hypothesis. Alimentary Pharmacology \& Therapeutics, 21, 1399-1409. http://dx.doi.org/10.1111/j.1365-2036.2005.02506.x

[10] Filippi, J., Al-Jaouni, R., Wiroth, J.B., Hébuterne, X. and Schneider, S.M. (2006) Nutritional Deficiencies in Patients with Crohn's Disease in Remission. Inflammatory Bowel Disease, 12, 185-191. http://dx.doi.org/10.1097/01.MIB.0000206541.15963.c3

[11] Bernstein, C.N., Fried, M., Krabshuis, J.H., Cohen, H., Eliakim, R., Fedail, S., Gearry, R., Goh, K.L., Hamid, S., Khan, A.G., LeMair, A.W., Malfertheiner, Ouyang, Q., Rey, J.F., Sood, A., Steinwurz, F., Thomsen, O.O., Thomson, A. and Watermeyer, G. (2010) World Gastroenterology Organization Practice Guidelines for the Diagnosis and Management of IBD in 2010. Inflammatory Bowel Disease, 16, 112-124. http://dx.doi.org/10.1002/ibd.21048

[12] Harvey, R.F. and Bradshaw, J.M. (1980) A Simple Index of Crohn's—Disease Activity. Lancet, 1, 514. http://dx.doi.org/10.1016/S0140-6736(80)92767-1

[13] Lichtiger, S., Present, D.H., Kornbluth, A., Gelernt, I., Bauer, J., Galler, G., Michelassi, F. and Haunauer, S. (1994) Cyclosporine in Severe Ulcerative Colitis Refractory to Steroid Therapy. The New England Journal of Medicine, 330, 1841-1845. http://dx.doi.org/10.1056/NEJM199406303302601

[14] Silverberg, M.S., Satsangi, J., Ahmad, T., Arnott, I.D., Bernstein, C.N., Brant, S.R., Caprilli, R., Colombel, J.F., Gasche, C., Geboes, K., Jewell, D.P., Karban, A., Loftus Jr., F.V., Peña, A.S., Riddell, R.H., Sachar, D.B., Schreiber, S., Steinhart, A.H., Targan, S.R., Vermeire, S. and Warren, B.F. (2005) Toward an Integrated Clinical, Molecular and Serological Classification of Inflammatory Bowel Disease: Report of a Working Party of the 2005 Montreal World Congress of Gastroenterology. Canadian Journal of Gastroenterology \& Hepatology, 19, 5-36.

[15] World Health Organization (1997) Report of a WHO Consulation on Obesity. Obesity, Preventing and Management the Global Epidemic. WHO, Geneva. 
[16] Nutrition Screening Initiative (1994) Incorporating Nutrition Screening and Interventions into Medical Practice. A Monograph for Phycicians. The Nutrition Screening Initiative. The American Dietetic Association, Washington DC.

[17] Ribeiro, A.B. and Cardoso, M.A. (2002) Development of a Food Frequency Questionnaire as a Tool for Programs of Chronic Diseases Prevention. Revista de Nutrição, 15, 239-245. http://dx.doi.org/10.1590/S1415-52732002000200012

[18] Institute of Medicine (2005) Food and Nutrition Board. Dietary Reference Intakes for Energy, Carbohydrate, Fiber, Fat, Fatty Acids, Cholesterol, Protein, and Amino Acids (Macronutrients). National Academy Press, Washington DC.

[19] Agdassi, E., Wendland, B.E., Stapleton, M., Raman, M. and Allard, J.P. (2007) Adequacy of Nutritional Intake in a Canadian Population of Patients with Crohn's Disease. Journal of the American Dietetic Association, 107, 1575-1580. http://dx.doi.org/10.1016/j.jada.2007.06.011

[20] Silva, A.F., Schieferdecker, A.E.M. and Amarante, H.M.B.S. (2011) Food Intake in Patients with Inflammatory Bowel Disease. ABCD. Arquivos Brasileiros de Cirurgia Digestiva (São Paulo), 24, 204-209. http://dx.doi.org/10.1590/S0102-67202011000300005

[21] Pesquisa de Orçamentos Familiares (2008-2009) AnÁlise do consumo alimentar pessoal no Brasil/IBGE, Coordenação de Trabalho e Rendimento. IBGE, Rio de Janeiro, 150 p. http://www.ibge.gov.br/home/eliacãoa/eliacão/condicaodevida/pof/2008_2009_analise_consumo/pofanalise_2008_200 9.pdf

[22] World Health Organization, Food and Agriculture Organization (2002) Diet, Nutrition and the Prevention of Chronic Diseases. Report of a Joint WHO/FAO Expert Consultation. World Health Organization, Geneva.

[23] Figueiredo, I.C., Jaime, P.C. and Monteiro, C.A. (2008) Factors Associated with Fruit and Vegetable Intake among Adults of the City of Sao Paulo, Southeastern Brazil. Revista de Saúde Pública, 42, 777-785. http://dx.doi.org/10.1590/S0034-89102008005000049

[24] Gary, T.L., Baptiste-Roberts, K., Gregg, E.W., Williams, D.E., Beckles, G.L., Miller 3rd, E.J. and Engelgau, M.M. (2004) Fruit, Vegetable and Fat Intake in a Population-Based Sample of African Americans. Journal of the National Medical Association, 96, 1599-1605.

[25] Ajani, U.A., Ford, E.S. and Mokdad, A.H. (2004) Dietary Fiber and C-Reactive Protein: Findings from National Health and Nutrition Examination Survey Data. Journal of Nutrition, 134, 1181-1185.

[26] Madruga, S.W., Araújo, C.L. and Bertoldi, A.D. (2009) Frequency of Fiber-Rich Food Intake and Associated Factors in a Southern Brazilian Population. Cadernos de Saúde Pública, 25, 2249-2259. http://dx.doi.org/10.1590/S0102-311X2009001000015

[27] Rose, D.J., DeMeo, M.T., Keshavarzian, A. and Hamaker, B.R. (2007) Influence of Dietary Fiber on Inflammatory Bowel Disease and Colon Cancer: Importance of Fermentation Pattern. Nutrition Reviews, 65, 51-62. http://dx.doi.org/10.1111/j.1753-4887.2007.tb00282.x

[28] Galvez, J., Rodriguez-Cabezas, M.E. and Zarzuelo, A. (2005) Effects of Dietary Fiber on Inflammatory Bowel Disease. Molecular Nutrition \& Food Research, 49, 601-608. http://dx.doi.org/10.1002/mnfr.200500013

[29] Scheppach, W., Luehrs, H., Melcher, R., Gostner, A., Schauber, J., Kudlich, T., Weiler, F. and Menzel, T. (2004) Antiinflammatory and Anticarcinogenic Effects of Dietary Fibre. Clinical Nutrition Supplements, 1, 51-58.

[30] Ananthakrishnan, A.N., Khalili, H., Konijeti, G.G., Higuchi, L.M., Silva, P., Korzenik, J.R., Fuchs, C.S., Willett, W.C., Richter, J.M. and Chan, A.T. (2013) A Prospective Study of Long-Term Intake of Dietary Fiber and Risk of Crohn's Disease and Ulcerative Colitis. Gastroenterology, 145, 970-977. http://dx.doi.org/10.1053/j.gastro.2013.07.050

[31] Hallert, C., Kaldma, M. and Petersson, B.G. (1991) Ispaghula Husk May Relieve Gastrointestinal Symptoms in U1cerative Colitis in Remission. Scandinavian Journal of Gastroenterology, 26, 747-750. http://dx.doi.org/10.3109/00365529108998594

[32] Fernández-Banares, F., Hinojosa, J., Sánchez-Lombraña, J.L., Navarro, E., Martinez-Salmerón, J.F., García-Pugés, A., González-Huix, F., Riera, J., González-Lara, V., Domínguez-Abascal, F., Giné, J.J., Moles, J., Gomollón, F. and Gassull, M.A. (1999) Randomized Clinical Trial of Plantago ovata Seeds (Dietary Fiber) as Compared with Mesalamine in Maintaining Remission in Ulcerative Colitis. Spanish Group for the Study of Crohn's Disease and Ulcerative Colitis (GETECCU). The American Journal of Gastroenterology, 94, 427-433. http://dx.doi.org/10.1111/j.1572-0241.1999.872_a.X

[33] Richman, E. and Rhodes, J.M. (2013) Review Article: Evidence-Based Dietary Advice for Patients with Inflammatory Bowel Disease. Alimentary Pharmacology \& Therapeutics, 38, 1156-1171. http://dx.doi.org/10.1111/apt.12500

[34] Hou, J.K., Lee, D. and Lewis, J. (2013) Diet and Inflammatory Bowel Disease: Review of Patient-Targeted Recommendations. Clinical Gastroenterology and Hepatology, 6, 1-9.

[35] Abraham, C. and Cho, J.H. (2009) Inflammatory Bowel Disease. The New England Journal of Medicine, 361, 20662078. http://dx.doi.org/10.1056/NEJMra0804647 
[36] Gearry, R.B., Richardson, A., Frampton, C.M., Collett, J.A., Burt, M.J., Chapman, B.A. and Barclay, M.L. (2006) High Incidence of Crohn's Disease in Canterbury, New Zealand: Results of an Epidemiologic Study. Inflammatory Bowel Diseases, 12, 936-943. http://dx.doi.org/10.1097/01.mib.0000231572.88806.b9 